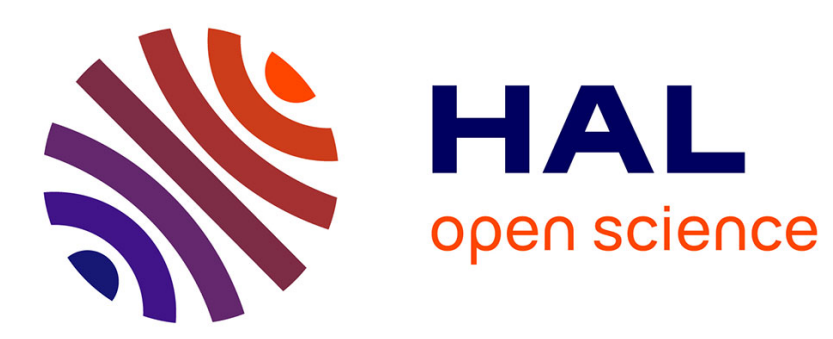

\title{
Highly Cytotoxic Copper(II) Terpyridine Complexes as Anticancer Drug Candidates
}

Johannes Karges, Kai Xiong, Olivier Blacque, Hui Chao, Gilles Gasser

\section{To cite this version:}

Johannes Karges, Kai Xiong, Olivier Blacque, Hui Chao, Gilles Gasser. Highly Cytotoxic Copper(II) Terpyridine Complexes as Anticancer Drug Candidates. Inorganica Chimica Acta Reviews, 2020, pp.120137. 10.1016/j.ica.2020.120137 . hal-03007260

\section{HAL Id: hal-03007260 \\ https://hal.science/hal-03007260}

Submitted on 16 Nov 2020

HAL is a multi-disciplinary open access archive for the deposit and dissemination of scientific research documents, whether they are published or not. The documents may come from teaching and research institutions in France or abroad, or from public or private research centers.
L'archive ouverte pluridisciplinaire HAL, est destinée au dépôt et à la diffusion de documents scientifiques de niveau recherche, publiés ou non, émanant des établissements d'enseignement et de recherche français ou étrangers, des laboratoires publics ou privés. 


\section{Highly Cytotoxic Copper(II) Terpyridine Complexes as Anticancer Drug Candidates}

Johannes Karges ${ }^{a}$, Kai Xiong $^{b}$, Olivier Blacque $^{c}, H_{u i}$ Chao $^{b, *}$ and Gilles Gasser $^{a, *}$

a Chimie ParisTech, PSL University, CNRS, Institute of Chemistry for Life and Health Sciences, Laboratory for Inorganic Chemical Biology, 75005 Paris, France.

b MOE Key Laboratory of Bioinorganic and Synthetic Chemistry, School of Chemistry, Sun Yat-Sen University, 510275 Guangzhou, People’s Republic of China.

c Department of Chemistry, University of Zurich, Winterthurerstrasse 190, CH-8057, Zurich, Switzerland.

*Email: $\quad$ ceschh@mail.sysu.edu.cn, $\quad$ Tel. $\quad+86 \quad 20 \quad 84110613$; $\quad$ Email: gilles.gasser@chimieparistech.psl.eu; Tel. +33 1442756 02; WWW: www.gassergroup.com,

ORCID-ID:

Johannes Karges: 0000-0001-5258-0260

Olivier Blacque: 0000-0001-9857-4042

Hui Chao: 0000-0003-4153-5303

Gilles Gasser: 0000-0002-4244-5097

Keywords: Anticancer, Antineoplastic Agents, Medicinal Inorganic Chemistry, Metals in Medicine, Toxicity. 


\begin{abstract}
Cancer is one of the deadliest diseases worldwide. Chemotherapy remains one of the frequently applied treatment modalities in the clinics. However, as the currently applied agents are associated with severe side effects, scientists are searching for novel chemotherapeutic drugs. Within the last decades, $\mathrm{Cu}$ (II) polypyridine complexes have received increasing attention as potential anticancer drug candidates. Herein, the biological activity of terminally functionalised mono- and bis-coordinated $\mathrm{Cu}(\mathrm{II})-2,2^{\prime}: 6^{\prime}, 2^{\prime \prime}$-terpyridine complexes have been investigated. The bis-coordinated compounds were found to have a cytotoxic effect in the nanomolar range in human adenocarcinomic alveolar basal epithelial cells. Promisingly, the complexes were equally active in the corresponding cisplatin resistant cell line, indicating that they could potentially be useful for the treatment of drug resistant tumours.
\end{abstract}

\title{
HIGHLIGHTS
}

- Synthesis of terminally functionalised $\mathrm{Cu}(\mathrm{II})$ polypyridine of the type $\left[\mathrm{Cu}\left(2,2^{\prime}: 6^{\prime}, 2^{\prime \prime}\right.\right.$ terpyridine $\left.)(\mathrm{Cl})_{2}\right]$ and $\left[\mathrm{Cu}\left(2,2^{\prime}: 6^{\prime}, 2^{\prime \prime} \text {-terpyridine }\right)_{2}\right]\left[\mathrm{NO}_{3}\right]_{2}$.

- Single crystal X-ray analysis of metal complexes.

- Biological evaluation revealed cytotoxicity of lead compounds in the nanomolar range against human adenocarcinomic alveolar basal epithelial cells.

- Effective in drug resistant cancer cell line.

\section{GRAPHICAL ABSTRACT}

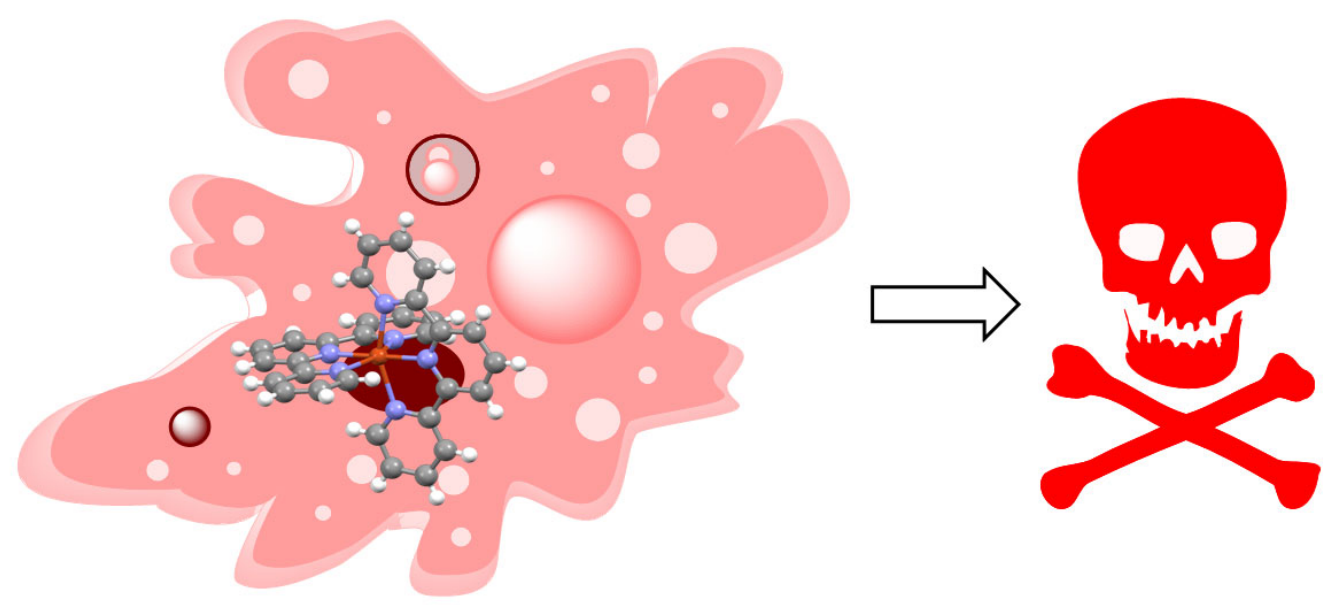




\section{INTRODUCTION}

Cancer remains one of leading causes of death worldwide as demonstrated by the alarming numbers published by World Health Organisation (WHO) over the last decades.[1] As treatment modalities, chemotherapy is commonly applied in the clinics in combination with radiotherapy, immunotherapy and surgery to circumvent the limitations of each treatment and overall improve the chances of eradication of the tumour and therefore survival of the patient.[2]

To date, the platinum based agents cisplatin, oxaliplatin and carboplatin are clinically applied in more than $50 \%$ of chemotherapeutic treatments worldwide.[3, 4] Despite their enormous success, these compounds are not ideal and associated with numerous side effects including nerve and kidney damage, nausea, vomiting, and bone marrow suppression. More worryingly, the number of resistant cancers is increasing, limiting the application of these compounds.[5-8] To tackle this issue, scientists from all over the world are searching for novel chemotherapeutic agents. While the majority of investigated metal complexes are based on rare transition metals, it would be very interesting to develop compounds based on cheap and abundant metals.[9-16]

Among other investigated metals, copper containing compounds are receiving increasing attention due their bioavailability and biocompatibility. The possibility of the reversible change of the oxidation state of the $\mathrm{Cu}(\mathrm{I}) / \mathrm{Cu}$ (II) couple under physiological conditions is appealing and has promoted the development of metal complexes with an active redox chemistry within cancerous cells. While $\mathrm{Cu}$ (II) polypyridine complexes have shown to interact with DNA, they were found to oxidatively cleave the phosphodiester bond through the generation of reactive oxygen species. These effects can cause DNA strand breaks and ultimately trigger cell death.[17-19] The first example of such compounds was the $\left[\mathrm{Cu}(1,10-\text { phenanthroline })_{2}\right]^{2+}$ complex, which was found to cleave DNA of Escherichia coli bacteria.[20] Based on these attractive properties, $\mathrm{Cu}(\mathrm{II})$ polypyridine complexes are receiving increasing attention as artificial nucleases as well as potential anticancer candidates.[21-26] It is important to note, that two of such compounds, referred to as Casiopeinas ${ }^{\circledR}$, are currently investigated in clinical trials.[27, 28] Further the complex diacetylbis(4-methylthiosemicarbazonato)copper(II), also abbreviated as copper-ATSM, is under investigation in clinical trials for the treatment of motor neurone disease.[29, 30]

As a class of compounds with particular interest, complexes of the type $\left[\mathrm{Cu}\left(2,2^{\prime}: 6^{\prime}, 2^{\prime \prime}\right.\right.$ terpyridine $\left.(\mathrm{Cl})_{2}\right]$ have been studied. The terminal extension of the ligand with piperidine, bis(2-pyridylmethyl)amine[31, 32], naphthalene[33], anthracene[34] as well as diverse substituted phenyl groups[35] including their multinuclear complexes have generated cytotoxic 
agents against various cancer cell lines. Worthy of note, the naphthalene derivative with a labile nitrate and water molecule instead of chloride ligands, was also found to be cytotoxic against cancerous cells.[36] The vast majority of these complexes demonstrated to strongly bind to DNA through an intercalative mode. While being able to efficiently cleave DNA, the compounds were found to be cytotoxic in the low micromolar to nanomolar range, making this class of compounds interesting candidates as anticancer agents.

Considering these promising results, herein, a series of terminally functionalised complexes of the type $\left[\mathrm{Cu}\left(2,2^{\prime}: 6^{\prime}, 2^{\prime \prime}\right.\right.$-terpyridine $\left.)(\mathrm{Cl})_{2}\right]$ 1-6 and $\left[\mathrm{Cu}\left(2,2^{\prime}: 6^{\prime}, 2^{\prime \prime} \text {-terpyridine }\right)_{2}\right]\left[\mathrm{NO}_{3}\right]_{2}$ 7-12 were synthesised and their cytotoxicity towards cancer cells investigated. We note that during the writing-up of this article, compounds $\mathbf{2}$ and $\mathbf{8}$ (with perchlorate as counter ions) were reported as cytotoxic agents against ovarian carcinoma cells by Gamez and co-workers. This study indicated that these compounds strongly interact with DNA and trigger cell death by apoptosis.[33] The compounds reported in our work were synthesised by complexation of the functionalised 2,2':6',2' -terpyridine derivative with $\mathrm{CuCl}_{2}$ or $\mathrm{CuNO}_{3} \cdot \mathrm{xH}_{2} \mathrm{O}$. Several complexes were also characterised by single crystal X-ray crystallography. The bis-coordinated complexes were found to be cytotoxic in the nanomolar range in adenocarcinomic human alveolar basal epithelial (A549) cells. Promisingly, the $\mathrm{Cu}$ (II) complexes were found to be toxic in the corresponding cisplatin resistant cell line, making them potentially interesting as anticancer agents against drug resistant tumours.

\section{EXPERIMENTAL SECTION}

\subsection{Materials}

All chemicals were obtained from commercial sources and used without further purification. Solvents were dried over molecular sieves if necessary. The substituted 2,2':6',2"'-terpyridine ligands (terpy-X): 4'-chloro-2,2':6',2”-terpyridine (terpy-Cl)[37], 4'-bromo-2,2':6',2”terpyridine (terpy-Br)[38], 4'-methoxy-2,2’:6’,2”-terpyridine (terpy-OMe)[39], 4'-carboxy2,2':6',2”-terpyridine (terpy-COOH)[40], 4'-dimethylamino-2,2':6',2”-terpyridine (terpy$\mathrm{NMe}_{2}$ )[41] were synthesised as previously reported.

\subsection{Instrumentation and methods}


ESI-MS experiments were carried out using a LTQ-Orbitrap XL from Thermo Scientific (Thermo Fisher Scientific) and operated in positive ionization mode, with a spray voltage at 3.6 $\mathrm{kV}$. No Sheath and auxiliary gas was used. Applied voltages were 40 and $100 \mathrm{~V}$ for the ion transfer capillary and the tube lens, respectively. The ion transfer capillary was held at $275^{\circ} \mathrm{C}$. Detection was achieved in the Orbitrap with a resolution set to 100,000 (at m/z 400) and a $\mathrm{m} / \mathrm{z}$ range between 150-2000 in profile mode. Spectrum was analyzed using the acquisition software XCalibur 2.1 (Thermo Fisher Scientific). The automatic gain control (AGC) allowed accumulation of up to $2 \cdot 10^{5}$ ions for FTMS scans, maximum injection time was set to $300 \mathrm{~ms}$ and $1 \mu$ scan was acquired. $10 \mu \mathrm{L}$ was injected using a Thermo Finnigan Surveyor HPLC system (Thermo Fisher Scientific) with a continuous infusion of methanol at $100 \mu \mathrm{L} \cdot \mathrm{min}^{-1}$. Infrared (IR) spectra ( $\mathrm{w}=$ weak, $\mathrm{m}=$ medium, $\mathrm{s}=$ strong, br=broad) were measured with a Nicolet 6700 FTIR spectrometer (Thermo Scientific). Elemental microanalyses were performed on a Thermo Flash 2000 elemental analyser.

\subsection{Synthesis}

\section{General procedure for the synthesis of $\left[\mathrm{Cu}(\operatorname{terpy}-\mathrm{X})(\mathrm{Cl})_{2}\right]$ :}

$\mathrm{CuCl}_{2}$ (40 mg, $0.30 \mathrm{mmol}$ ) was dissolved in $20 \mathrm{~mL}$ of dry methanol under $\mathrm{N}_{2}$ atmosphere. A solution of the terpy-X ligand $(70-83 \mathrm{mg}, 0.30 \mathrm{mmol})$ in dry methanol/dichloromethane $(1: 1$, $20 \mathrm{~mL}$ ) was added dropwise. The mixture was stirred vigorously for $24 \mathrm{~h}$ at room temperature. The generated precipitate was isolated by filtration and washed with diethyl ether $(10 \mathrm{~mL})$ and dichloromethane $(10 \mathrm{~mL})$. The crude product was purified by recrystallisation from methanol.

\section{General procedure for the synthesis of $\left[\mathrm{Cu}(\operatorname{terpy}-\mathrm{X})_{2}\right]\left[\mathrm{NO}_{3}\right]_{2}$ :}

A solution of the terpy-X ligand $(70-83 \mathrm{mg}, 0.30 \mathrm{mmol})$ was dissolved in dry methanol/dichloromethane $(1: 1,20 \mathrm{~mL})$ under $\mathrm{N}_{2}$ atmosphere. A solution of $\mathrm{Cu}\left(\mathrm{NO}_{3}\right)_{2} \cdot \mathrm{xH}_{2} \mathrm{O}$ (56 mg, $0.15 \mathrm{mmol}$ ) was dissolved in $20 \mathrm{~mL}$ of dry methanol was added dropwise. The mixture was stirred vigorously for $24 \mathrm{~h}$ at room temperature. The generated precipitate was isolated by filtration and washed with diethyl ether $(10 \mathrm{~mL})$ and dichloromethane $(10 \mathrm{~mL})$. The crude product was purified by recrystallisation from methanol. 
[Cu(terpy-H)(Cl) 2$]$ (1): Yield: 73\%, ESI-HRMS (pos. detection mode): calcd for $\mathrm{C}_{15} \mathrm{H}_{11} \mathrm{Cl}_{1} \mathrm{CuN}_{3} \mathrm{~m} / \mathrm{z}$ [M-Cl] $]^{+}$330.9932; found: 330.9932, FT-IR: 3014 (brw), 1597 (m), 1578 (w), 1475 (m), 1448 (s), 1329 (w), 1304 (w), 1255 (w), 1167 (w), 1034 (w), 1020 (m), 791 (m), 769 (s), 748 (m), 729 (m) cm $\mathrm{cm}^{-1}$, Elemental analysis calcd for $\mathrm{C}_{15} \mathrm{H}_{11} \mathrm{Cl}_{2} \mathrm{CuN}_{3}(\%)$ : $\mathrm{C}$ 48.97, $\mathrm{H}$ 3.02, N 11.43; found: C 49.15, H 3.24, N 11.27.

[Cu(terpy-CI)(CI)2] (2):Yield: 82\%, FT-IR: 3012 (brw), 1597 (m), 1578 (w), 1473 (m), 1446 (s), 1324 (w), $1301(\mathrm{w}), 1255$ (w), 1167 (w), 1033 (w), 1020 (m), 791 (m), 770 (s), 748 (m), 730 (m) $\mathrm{cm}^{-1}$, ESI-HRMS (pos. detection mode): calcd for $\mathrm{C}_{15} \mathrm{H}_{10} \mathrm{Cl}_{2} \mathrm{CuN}_{3} \mathrm{~m} / \mathrm{z}[\mathrm{M}-\mathrm{Cl}]^{+}$ 364.9542; found: 364.9541, Elemental analysis calcd for $\mathrm{C}_{15} \mathrm{H}_{10} \mathrm{Cl}_{3} \mathrm{CuN}_{3}$ (\%): $\mathrm{C} 44.78, \mathrm{H} 2.51$, N 10.45; found: C 44.97, H 2.63, N 10.28.

[Cu(terpy-Br)(CI)2] (3): Yield: 68\%, FT-IR: 3043 (brw), 1585 (m), 1556 (m), 1471 (m), 1414 (s), 1246 (w), 1109 (w), 1020 (m), 891 (m), 787 (s), 748 (m), 729 (m) cm', ESI-HRMS (pos. detection mode): calcd for $\mathrm{C}_{15} \mathrm{H}_{10} \mathrm{BrClCuN}_{3} \mathrm{~m} / \mathrm{z}$ [M-Cl] $]^{+}$408.9037; found: 408.9037, Elemental analysis calcd for $\mathrm{C}_{15} \mathrm{H}_{10} \mathrm{BrCl}_{2} \mathrm{CuN}_{3}$ (\%): C 40.32, H 2.26, N 9.41; found: $\mathrm{C} 40.60$, H 2.07, N 9.39.

[Cu(terpy-COOH)(Cl)2] (4): Yield: 41\%, FT-IR: 3012 (brw), 1709 (m), 1603 (m), 1570 (m), 1471 (m), 1417 (s), 1387 (m), 1301 (m), 1190 (s), 1151 (m), 1109 (w), 1018 (m), 874 (m), 799 (m), $766(\mathrm{~s}), 723(\mathrm{~m}), 706(\mathrm{~m}), 729(\mathrm{~m}), 671(\mathrm{~s}) \mathrm{cm}^{-1}$, ESI-HRMS (pos. detection mode): calcd for $\mathrm{C}_{16} \mathrm{H}_{11} \mathrm{ClCuN}_{3} \mathrm{O}_{2} \mathrm{~m} / \mathrm{z}$ [M-Cl] 374.9830 ; found: 374.9831, Elemental analysis calcd for $\mathrm{C}_{16} \mathrm{H}_{11} \mathrm{Cl}_{2} \mathrm{CuN}_{3} \mathrm{O}_{2}$ (\%): C 46.65, H 2.69, N 10.21; found: C 46.83, H 2.88, N 10.34.

[Cu(terpy-OMe)(Cl)2] (5): Yield: 56\%, FT-IR: 3012 (brw), 1600 (m), 1572 (w), 1479 (m), 1436 (m), 1416 (m), 1373 (m), 1228 (s), 1161 (w), 1059 (m), 1036 (s), 1018 (m), 874 (w), 796 (s), $750(\mathrm{~m}), 729(\mathrm{~m}) \mathrm{cm}^{-1}$, ESI-HRMS (pos. detection mode): calcd for $\mathrm{C}_{16} \mathrm{H}_{13} \mathrm{ClCuN}_{3} \mathrm{O} \mathrm{m} / \mathrm{z}$ [M-Cl] 361.0038; found: 361.0040, Elemental analysis calcd for $\mathrm{C}_{16} \mathrm{H}_{13} \mathrm{Cl}_{2} \mathrm{CuN}_{3} \mathrm{O}$ (\%): C 48.29, H 3.30, N 10.57; found: C 48.53, H 3.47, N 10.34.

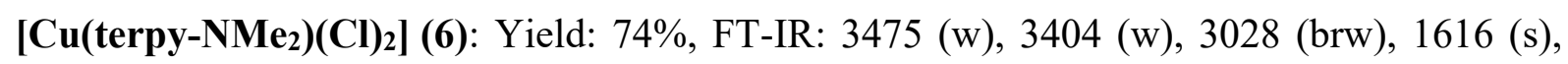
$1570(\mathrm{w}), 1541$ (m), 1475 (m), 1432 (m), 1416 (m), 1391 (w), 1303 (w), 1153 (w), $1051(\mathrm{w})$, 1026 (s), 849 (m), 795 (s), 750 (w), 721 (w), $692(\mathrm{w}) \mathrm{cm}^{-1}$, ESI-HRMS (pos. detection mode): calcd for $\mathrm{C}_{17} \mathrm{H}_{16} \mathrm{ClCuN}_{4} \mathrm{~m} / \mathrm{z}$ [M-Cl] 374.0354 ; found: 374.0354 , Elemental analysis calcd for $\mathrm{C}_{17} \mathrm{H}_{16} \mathrm{Cl}_{2} \mathrm{CuN}_{4}$ (\%): C 49.68, H 3.93, N 13.64; found: C 49.96, H 4.13, N 13.35.

[Cu(terpy-H) $\left.)_{2}\right]\left[\mathrm{NO}_{3}\right]_{2}$ (7): Yield: 67\%, FT-IR: 3489 (brw), 3079 (brw), 1600 (w), 1575 (w), 1477 (m), 1450 (m), 1362 (s), 1331 (s), 1317 (s), 1306 (s), 1161 (m), 1043 (w), 1024 (m), 829 
(m), $775(\mathrm{~s}), 735(\mathrm{~m}) \mathrm{cm}^{-1}$, ESI-HRMS (pos. detection mode): calcd for $\mathrm{C}_{30} \mathrm{H}_{22} \mathrm{CuN}_{6} \mathrm{~m} / \mathrm{z}[\mathrm{M}]^{2+}$ 264.5595; found: 264.5596, Elemental analysis calcd for $\mathrm{C}_{30} \mathrm{H}_{22} \mathrm{CuN}_{8} \mathrm{O}_{6}(\%)$ : C 55.09, H 3.39, N 17.13; found: C 55.30, H 3.42, N 16.97.

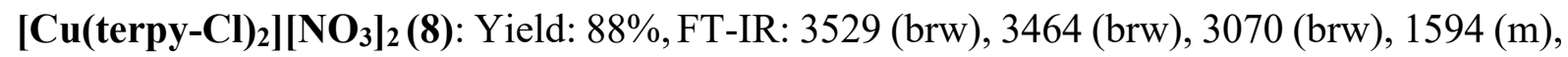
1574 (w), 1560 (w), 1475 (w), 1419 (s), 1342 (s), 1305 (s), 1274 (s), 1241 (m), 1112 (w), 1018 (s), 827 (s), 798 (s), 752 (w), 729 (w) $\mathrm{cm}^{-1}$, ESI-HRMS (pos. detection mode): calcd for $\mathrm{C}_{30} \mathrm{H}_{20} \mathrm{Cl}_{2} \mathrm{CuN}_{6} \mathrm{~m} / \mathrm{z}[\mathrm{M}]^{2+}$ 298.5206; found: 298.5202, Elemental analysis calcd for $\mathrm{C}_{30} \mathrm{H}_{20} \mathrm{Cl}_{2} \mathrm{CuN}_{8} \mathrm{O}_{6}$ (\%): C 49.84, H 2.79, N 15.50; found: C 50.15, H 2.84, N 15.73.

[Cu(terpy-Br)2][NO $]_{2}$ (9): Yield: 82\%, FT-IR: 3457 (brw), 3068 (brw), 1587 (m), 1571 (w), 1558 (m), 1473 (m), 1417 (s), 1338 (s), 1308 (s), 1280 (s), 1245 (m), 1113 (w), 1018 (m), 1008 (m), $875(\mathrm{w}), 829(\mathrm{w}), 791(\mathrm{~s}), 748(\mathrm{w}), 727(\mathrm{w}) \mathrm{cm}^{-1}$, ESI-HRMS (pos. detection mode): calcd for $\mathrm{C}_{30} \mathrm{H}_{20} \mathrm{Br}_{2} \mathrm{CuN}_{6} \mathrm{~m} / \mathrm{z}[\mathrm{M}]^{2+}$ 343.4690; found: 343.4679, Elemental analysis calcd for $\mathrm{C}_{30} \mathrm{H}_{20} \mathrm{Br}_{2} \mathrm{CuN}_{8} \mathrm{O}_{6}$ (\%): C 44.38, H 2.48, N 13.80; found: C 44.31, H 2.62, N 13.74.

[Cu(terpy-COOH) $\left.)_{2}\right]\left[\mathrm{NO}_{3}\right]_{2}$ (10): Yield: 57\%, FT-IR: 3531 (brw), 3463 (brw), 3064 (brw), 1706 (m), 1625 (m), 1606 (w), 1562 (w), 1475 (w), 1388 (s), 1317 (s), 1295 (s), 1284 (s), 1236 (m), 1022 (m), 1008 (m), 827 (m), 798 (s), 752 (w), 728 (w) cm cm $^{-1}$ ESI-HRMS (pos. detection mode): calcd for $\mathrm{C}_{32} \mathrm{H}_{22} \mathrm{CuN}_{6} \mathrm{O}_{4} \mathrm{~m} / \mathrm{z}[\mathrm{M}]^{2+}$ 308.5494; found: 308.5482, Elemental analysis calcd for $\mathrm{C}_{32} \mathrm{H}_{22} \mathrm{CuN}_{8} \mathrm{O}_{10}$ (\%): C 51.79, H 2.99, N 15.10; found: C 52.09, H 3.16, N 15.04.

[Cu(terpy-OMe) $\left.{ }_{2}\right]\left[\mathrm{NO}_{3}\right]_{2}$ (11): Yield: 88\%, FT-IR: 3511 (brw), 3442 (brw), 3076 (brw), 1616 (m), 1603 (w), 1574 (w), 1562 (w), 1481 (m), 1438 (m), 1417 (m), 1346 (s), 1309 (s), 1228 (s), 1157 (m), 1037 (m), 1008 (m), 829 (w), 776 (s), 734 (w) cm ${ }^{-1}$, ESI-HRMS (pos. detection mode): calcd for $\mathrm{C}_{32} \mathrm{H}_{26} \mathrm{CuN}_{6} \mathrm{O}_{2} \mathrm{~m} / \mathrm{z}$ [M] ${ }^{2+}$ 294.5701; found: 294.5698, Elemental analysis calcd for $\mathrm{C}_{32} \mathrm{H}_{26} \mathrm{CuN}_{8} \mathrm{O}_{8}$ (\%): C 53.82, H 3.67, N 15.69; found: C 53.71, H 3.50, N 15.47.

[Cu(terpy-NMe $\left.)_{2}\right]\left[\mathbf{N O}_{3}\right]_{2}$ (12): Yield: 74\%, FT-IR: 3519 (brw), 3436 (brw), 3089 (brw), 1622 (m), 1604 (w), 1571 (w), 1556 (m), 1537 (m), 1469 (m), 1438 (m), 1432 (m), 1392 (m), 1344 (s), $1301(\mathrm{w}), 1157$ (w), $1028(\mathrm{~m}), 1006$ (m), 998 (m), 848 (m), 815 (w), $789(\mathrm{~s}), 744$ (w), 731 (w) $\mathrm{cm}^{-1}$, ESI-HRMS (pos. detection mode): calcd for $\mathrm{C}_{34} \mathrm{H}_{32} \mathrm{CuN}_{8} \mathrm{~m} / \mathrm{z}[\mathrm{M}]^{2+}$ 307.6017; found: 307.6010, Elemental analysis calcd for $\mathrm{C}_{34} \mathrm{H}_{32} \mathrm{CuN}_{10} \mathrm{O}_{6}$ (\%): C 55.17, H 4.36, N 18.92; found: C 54.93, H 4.54, N 18.68.

\subsection{Single crystal X-ray diffraction}


All single crystal X-ray diffraction analyses were performed on Rigaku Oxford Diffraction instruments: the XtaLAB Synergy diffractometer (Pilatus $200 \mathrm{~K}$ detector) for $\mathbf{3}$ and $\mathbf{5}$, and the SuperNova diffractometer (Atlas CCD detector) for 6, 7 and 11. Both instruments are dual microfocus X-ray diffractometers (two possible wavelengths $\mathrm{Mo}$ and $\mathrm{Cu}$ ) equipped with Oxford liquid-nitrogen cryostream coolers. The selected single crystals were mounted using polybutene oil on a flexible loop fixed on a goniometer head and transferred to the diffractometer. Preexperiments, data collections, data reductions and analytical absorption corrections[42] were performed with the program suite CrysAlisPro.[43] Using Olex2,[44] the structures were solved with the SHELXT[45] small molecule structure solution program and refined with the SHELXL2018/3 program package[46] by full-matrix least-squares minimization on $\mathrm{F}^{2}$. All nonhydrogen atoms were refined anisotropically and hydrogen atoms were placed in calculated positions and refined as riding with $\mathrm{C}-\mathrm{H}=0.95 \AA$, $U_{\text {iso }}(\mathrm{H})=1.2 U_{\text {eq }}(\mathrm{C})$ (for aromatic), $\mathrm{C}-\mathrm{H}=$ $0.98 \AA, U_{\mathrm{iso}}(\mathrm{H})=1.5 U_{\mathrm{eq}}(\mathrm{C})$ (for methyl) and $\mathrm{O}-\mathrm{H}=0.85 \AA, U_{\mathrm{iso}}(\mathrm{H})=1.5 U_{\mathrm{eq}}(\mathrm{O})$ (for water). The crystal data collections and structure refinement parameters are shown in Tables S1 - S3 . CCDC 2034245 (for 3), 2034246 (for 5), 2034247 (for 6), 2034248 (for 7), and 2034249 (for 11) contain the supplementary crystallographic data for these compounds, and can be obtained free of charge from the Cambridge Crystallographic Data Centre via www.ccdc.cam.ac.uk/data_request/cif.

\subsection{Cell culture}

All the cells lines were obtained from the animal experimental Centre of Sun Yat-Sen University (Guangzhou, China). The cell lines human adenocarcinomic alveolar basal epithelial (A549), cisplatin resistant human adenocarcinomic alveolar basal epithelial (A549R) and human liver (LO2) were maintained in DMEM media supplemented with fetal bovine serum $(10 \%)$, penicillin (100 units $/ \mathrm{mL})$, streptomycin $(50$ units $/ \mathrm{mL})$ at $37{ }^{\circ} \mathrm{C}$ in a humidified atmosphere with $5 \% \mathrm{CO}_{2}$. The cisplatin resistance of A549R was maintained by cisplatin treatment $(1 \mu \mathrm{M})$ for one week every month. Before an experiment, the cells were passaged three times.

\subsection{Cytotoxicity assay}

The cytotoxicity of a sample was accessed using a 3-(4,5-dimethylthiazol-2-yl)-2,5diphenyltetrazolium bromide (MTT) assay. Cells were seeded in 96 well plates and allowed to adhere upon incubation for $24 \mathrm{~h}$. The cells were treated with increasing concentrations of the 
compounds diluted in cell media achieving a total volume of $200 \mu \mathrm{L}$. All cells were incubated in the dark for $44 \mathrm{~h}$. After this time, the media was replaced with fresh media containing MTT $(20 \mu \mathrm{L}, 5 \mathrm{mg} / \mathrm{mL})$. After $4 \mathrm{~h}$ incubation, the absorption at $595 \mathrm{~nm}$ in each well was determined with a SpectraMax CMax Plus (Molecular Devices) absorbance microplate reader. The viability of the cells in each well was obtained by subtracting the average absorbance of the blank group.

\section{RESULTS AND DISCUSSION}

\subsection{Synthesis}

The terminally functionalised $2,2^{\prime}: 6^{\prime}, 2^{\prime \prime}$-terpyridine ligands were prepared according to previously published synthetic procedures (Scheme S1).[37-41, 47] The synthesis of the complexes 1[48-50], 2[51], 7[52-55], 8[56], 10[57] and 11[58] has been previously reported while, to the best of our knowledge, the synthesis of 3-6, 9 and $\mathbf{1 2}$ is reported here for the first time. The mono-coordinated dichloro complexes 1-6 were synthesised with one equivalent of the ligand and $\mathrm{CuCl}_{2}$ whereas the bis-coordinated complexes 7-12 were prepared with two equivalents of the ligand and $\mathrm{Cu}\left(\mathrm{NO}_{3}\right)_{2} \cdot \mathrm{xH}_{2} \mathrm{O}$ at room temperature. The compounds were isolated by recrystallisation from methanol and characterised using HR-MS spectrometry and IR spectroscopy (Figure S1-S12). The purity of the complexes was confirmed by elemental analysis. Worthy of note, previous studies on $\mathrm{Cu}$ (II) $2,2^{\prime}: 6^{\prime}, 2^{\prime \prime}$-terpyridine complexes have suggested the high stability of such compounds in a biological environment.[31-33]
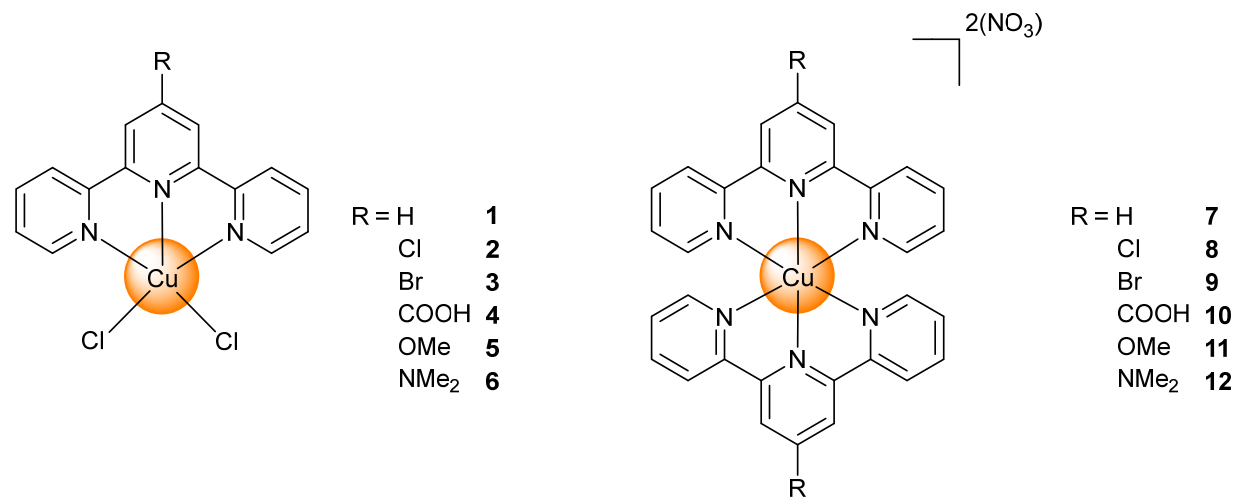

Figure 1. Chemical structures of the terminally-functionalised complexes of the type $\left[\mathrm{Cu}\left(2,2^{\prime}: 6^{\prime}, 2^{\prime \prime}\right.\right.$-terpyridine $\left.)(\mathrm{Cl})_{2}\right] \mathbf{1 - 6}$ and $\left[\mathrm{Cu}\left(2,2^{\prime}: 6^{\prime}, 2^{\prime \prime} \text {-terpyridine }\right)_{2}\right]\left[\mathrm{NO}_{3}\right]_{2} \mathbf{7 - 1 2}$. The biscoordinated complexes were isolated as nitrate salts. 


\subsection{X-ray crystallography}

Perspective views of the molecular structures of 3, 5, 6, 7 and $\mathbf{1 1}$ are shown in Figure 2. In the crystal structures of $\mathbf{5}$ and $\mathbf{6}$, the asymmetric units contain two crystallographically independent $\mathrm{Cu}$ (II) molecules and isolated molecule(s) of water (one for $\mathbf{5}$, and two for $\mathbf{6}$ ). In the crystal structure of 7 , the $\mathrm{Cu}(\mathrm{II})$ molecule lies on several special positions, a two fold axis and a rotoinversion four-fold axis. Only one fourth of the molecule had to be refined, the other positions were obtained by symmetry operations. The nitrate anions and water molecules are severely disordered around symmetry elements. Restraints had to be used to correct the geometry of the counterions and the thermal parameters of the corresponding atoms. In the crystal structure of $\mathbf{1 1}$, the asymmetric unit contains one $\mathrm{Cu}(\mathrm{II})$ molecule for two nitrate counterions and two isolated water molecules.

As revealed by the X-ray diffraction studies, the copper (II) atom in the terminally functionalised complexes of the type $\mathrm{Cu}\left(2,2^{\prime}: 6^{\prime}, 2^{\prime \prime}\right.$-terpyridine $)(\mathrm{Cl})_{2} \mathbf{3}(\mathrm{Br}), \mathbf{5}(\mathrm{OMe})$ and $\mathbf{6}$ $\left(\mathrm{NMe}_{2}\right)$ is pentacoordinated in a distorted square-pyramidal geometry by one terpyridyl ligand atoms and two chlorido ligands. The terpyridyl ligand is coordinated in an usual manner acting as a tridentate $\mathrm{N}^{3}$ chelating ligand while one chlorine atom is in an apical position and the second one is in the so-called "basal plane" formed by the latter and the three nitrogen atoms. As expected, these four atoms are nearly coplanar in our crystal structures as confirmed by the calculated r.m.s. deviations (Table 1) of 0.1110 (3), 0.0795 and 0.0937 (5), and 0.0602 and 0.0655 (6). The metal center and the apical $\mathrm{Cl}$ ion are located on the same side of the basal plane, the former deviates from the basal plane by about $0.2-0.3 \AA$ while the latter is at about $2.8 \AA$ (the exact values are reported in Table 1). Concerning the bond distances and angles, the $\mathrm{Cu}-\mathrm{N}$ bond of the central pyridine is shorter by about $0.1 \AA$ than those of the external rings, and the $\mathrm{Cu}-\mathrm{Cl}$ basal bond length is much shorter than the $\mathrm{Cu}-\mathrm{Cl}$ apical bond length by more than $0.2 \AA$ (Table 1). Such a difference between the $\mathrm{Cu}-\mathrm{Cl}$ distances is attributed to the wellknown Jahn Teller effect. In the crystal structures of the complexes of the type $\left[\mathrm{Cu}\left(2,2^{\prime}: 6^{\prime}, 2^{\prime \prime}-\right.\right.$

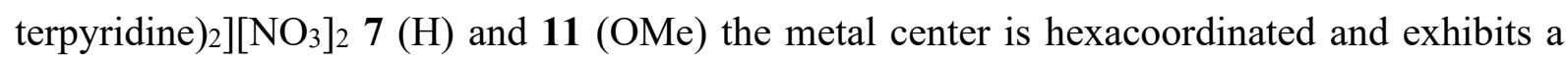
distorted octahedral coordination geometry. The two $\mathrm{N}^{3}$ coordinated terpyridyl ligands are nearly planar and perpendicular to each other in 7 (due to the $\mathrm{Cu}$ atom located on special positions) or nearly perpendicular in $\mathbf{1 1}$ since the dihedral angle between the mean plane is $87.24(3)^{\circ}$. Like in the dichloro complexes, the $\mathrm{Cu}-\mathrm{N}$ bond distance of the central pyridine is significantly smaller than those of the external rings (by $0.15-0.25 \AA$, Table 2). Despite the 
large number of aromatic rings in all our complexes, there are no strong $\pi^{\cdots} \pi$ interactions in the crystal structures. These interactions correspond to slipped face-to-face $\pi$ stacking with the shortest centroid - centroid distances of 3.573 (3), 3.493 (5), 3.594 (6), 3.634 (7) and $4.106 \AA$ (11) and slipped distances in the range $0.925-1.175 \AA$ (Tables 1 and 2).
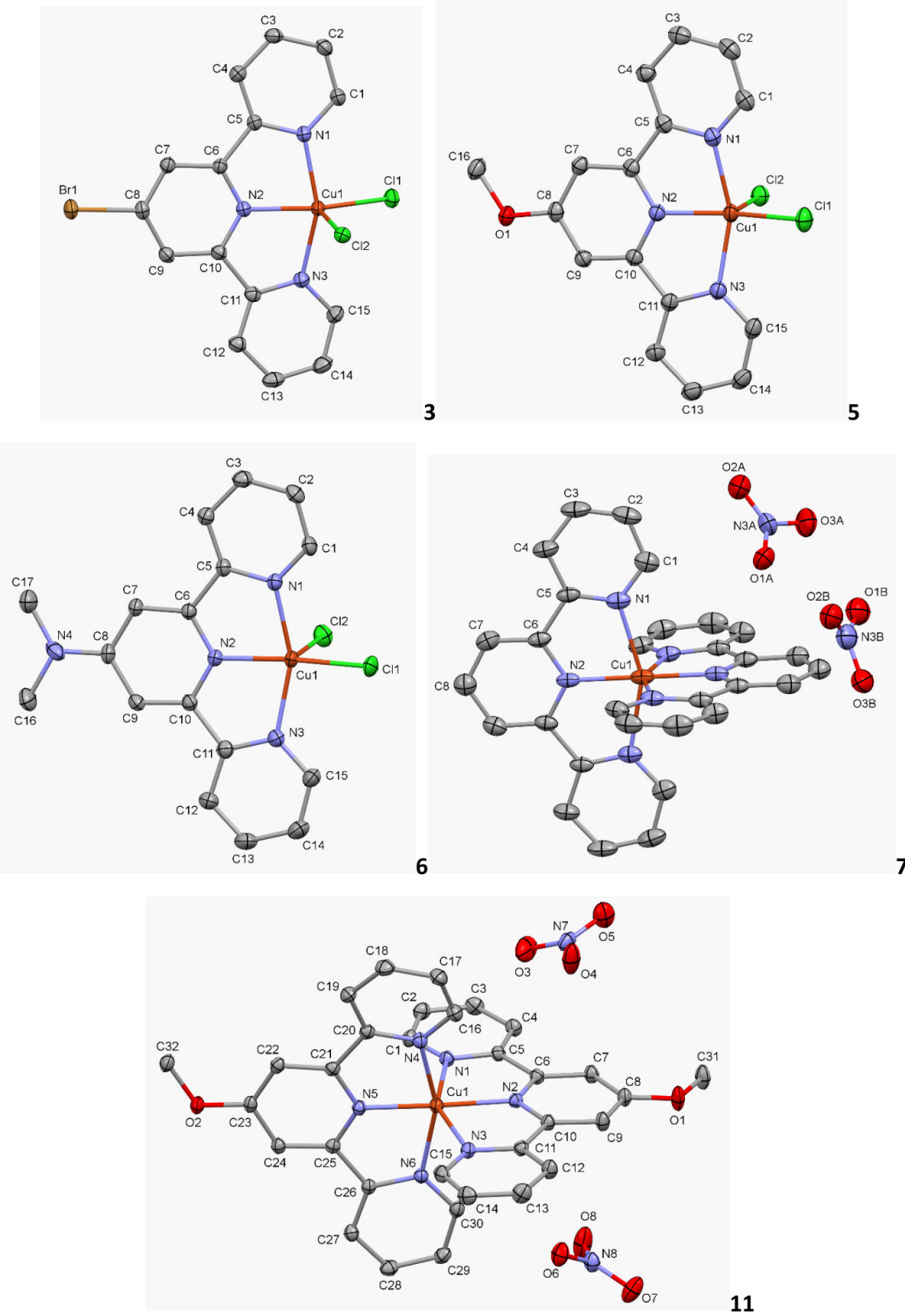

Figure 2. The molecular structure of $3,5,6,7$ and 11. Solvent molecules and hydrogen atoms are excluded for clarity. For $\mathbf{5}$ and $\mathbf{6}$, only one of the two crystallographically independent $\mathrm{Cu}$ (II) molecules is presented. 
Table 1. Selected geometrical parameters for 3, 5 and $\mathbf{6 .}$

\begin{tabular}{|c|c|c|c|c|c|}
\hline & 3 & & $5^{\mathrm{a}}$ & & $b^{a}$ \\
\hline $\mathrm{Cu}-\mathrm{N}_{\text {central }}(\AA)$ & $1.9718(16)$ & $1.9484(12)$ & $1.9503(12)$ & $1.9349(18)$ & $1.9356(19)$ \\
\hline \multirow{2}{*}{$\mathrm{Cu}-\mathrm{N}_{\text {lateral }}(\AA)$} & $2.0428(16)$ & $2.0413(13)$ & $2.0497(13)$ & $2.0407(19)$ & $2.0448(15)$ \\
\hline & $2.0442(17)$ & $2.0604(13)$ & $2.0538(13)$ & $2.0503(19)$ & $2.0490(19)$ \\
\hline $\mathrm{Cu}-\mathrm{Cl}_{\text {basal }}(\AA)$ & $2.2534(5)$ & $2.2362(4)$ & $2.2493(4)$ & $2.2337(6)$ & $2.2302(6)$ \\
\hline $\mathrm{Cu}-\mathrm{Cl}_{\text {apical }}(\AA)$ & $2.4642(5)$ & $2.4921(4)$ & $2.4939(4)$ & $2.5678(6)$ & $2.5501(7)$ \\
\hline $\mathrm{Cl}-\mathrm{Cu}-\mathrm{Cl}$ (deg.) & $104.532(19)$ & $104.514(16)$ & $105.314(15)$ & $98.75(2)$ & $99.00(2)$ \\
\hline r.m.s. deviation ${ }^{\mathrm{b}}$ & 0.1110 & 0.0795 & 0.0937 & 0.0655 & 0.0602 \\
\hline $\mathrm{Cu}(\AA)^{\mathrm{c}}$ & $0.3479(8)$ & $0.2930(6)$ & $0.3314(6)$ & $0.2748(9)$ & $0.2724(9)$ \\
\hline $\mathrm{Cl}_{\text {apical }}(\AA)^{\mathrm{c}}$ & $2.8049(9)$ & $2.7735(7)$ & $2.8104(7)$ & $2.8405(10)$ & $2.8201(10)$ \\
\hline $\begin{array}{l}\text { shortest } \\
\text { centroid...centroid }(\AA)\end{array}$ & 3.573 & \multicolumn{2}{|c|}{3.493} & \multicolumn{2}{|c|}{3.634} \\
\hline slippage $(\AA)$ & 1.083 & \multicolumn{2}{|c|}{0.925} & \multicolumn{2}{|c|}{1.175} \\
\hline
\end{tabular}

Table 2. Selected geometrical parameters for 7 and $\mathbf{1 1 .}$

\begin{tabular}{lrr}
\hline & $\mathbf{7 a}$ & \multicolumn{1}{c}{$\mathbf{1 1}$} \\
\hline $\mathrm{Cu}-\mathrm{N} 1(\AA)$ & $2.1876(19)^{\mathrm{a}}$ & $2.2474(14)$ \\
$\mathrm{Cu}-\mathrm{N} 2(\AA)$ & $1.990(3)^{\mathrm{a}}$ & $2.0059(14)$ \\
$\mathrm{Cu}-\mathrm{N} 3(\AA)$ & & $2.2843(14)$ \\
$\mathrm{Cu}-\mathrm{N} 4(\AA)$ & & $2.0999(14)$ \\
$\mathrm{Cu}-\mathrm{N} 5(\AA)$ & & $1.9486(14)$ \\
$\mathrm{Cu}-\mathrm{N} 6(\AA)$ & 90 & $2.0907(13)$ \\
dihedral angle (deg.) & 3.634 & $87.24(3)$ \\
shortest centroid...centroid & & 4.106 \\
$(\AA)$ & 1.175 & - \\
slippage $(\AA)$ & \\
${ }^{a}$ the Cu atom lies on several special positions: a two fold \\
axis and a rotoinversion four-fold axis between the mean \\
planes of the terpyridyl ligands
\end{tabular}

\subsection{Biological Evaluation}

The mono-coordinated dichloro complexes 1-6 were found to be poorly soluble in water and showed limited solubility even upon the addition of DMSO. For this reason, their cytotoxicity was not investigated. On the contrary, the bis-coordinated complexes 7-12 were highly water soluble. For this reason, the cytotoxicity of only 7-12 towards cancerous human adenocarcinomic alveolar basal epithelial (A549), the corresponding cisplatin resistant version 
(A549R) and non-cancerous human liver (LO2) cells was investigated using a 3-(4,5dimethylthiazol-2-yl)-2,5-diphenyltetrazolium bromide (MTT) assay (Table 3). Previous studies have shown that the toxicity of $\mathrm{Cu}$ (II) $2,2^{\prime}: 6^{\prime}, 2^{\prime \prime}$-terpyridine complexes within a cellular model is highly increased upon incubation for several days.[33] Therefore, the complexes were incubated for $44 \mathrm{~h}$ and, after this time, the cell viability assessed. The complexes 7-9, 11-12 were found to be cytotoxic in the nanomolar range $\left(\mathrm{IC}_{50}=150-1030 \mathrm{nM}\right)$ in A549 cells. As an exception, the carboxylic acid functionalized compound $\mathbf{1 0}$ was significantly less toxic $\left(\mathrm{IC}_{50}=\right.$ $38.92 \pm 4.50 \mu \mathrm{M})$. As the $\mathrm{Cu}$ complexes showed a similar cytotoxic effect in the non-cancerous cell line LO2, no selectivity for cancerous cells was observed. Promisingly, all complexes showed a comparable effect in the cisplatin resistant cell line A549R, indicating that these compounds could potentially be useful to overcome drug resistance. As the lead structure of this study, complex 7 was identified with a cytotoxicity in the nanomolar range ( $\mathrm{IC}_{50}=80-180$ $\mathrm{nM}$ ). These results are very encouraging as this compound is 82-times more cytotoxic in A549 cells and 242-times more cytotoxic in its drug resistant version A549R than the clinically approved drug cisplatin. Recent studies have demonstrated that structurally related $\mathrm{Cu}$ (II) $2,2^{\prime}: 6^{\prime}, 2^{\prime \prime}$-terpyridine complexes trigger cell death by necrosis or apoptosis.[33]

Table 3. IC50 values $(\mu \mathrm{M})$ of the bis-coordinated $\mathrm{Cu}(\mathrm{II})$ complexes 7-12 against cancerous human adenocarcinomic alveolar basal epithelial (A549), cisplatin resistant human adenocarcinomic alveolar basal epithelial (A549R) and non-cancerous human liver (LO2) cells.

\begin{tabular}{|c|c|c|c|}
\hline Compound & $\mathbf{A 5 4 9}$ & $\mathbf{A 5 4 9 R}$ & LO2 \\
\hline $\mathbf{7}$ & $0.15 \pm 0.01$ & $0.18 \pm 0.07$ & $0.08 \pm 0.01$ \\
\hline $\mathbf{8}$ & $0.59 \pm 0.05$ & $0.64 \pm 0.04$ & $0.23 \pm 0.02$ \\
\hline $\mathbf{9}$ & $1.03 \pm 0.07$ & $0.93 \pm 0.11$ & $0.52 \pm 0.06$ \\
\hline $\mathbf{1 0}$ & $38.92 \pm 4.50$ & $40.02 \pm 3.56$ & $21.35 \pm 0.95$ \\
\hline $\mathbf{1 1}$ & $0.73 \pm 0.03$ & $0.60 \pm 0.08$ & $0.37 \pm 0.01$ \\
\hline $\mathbf{1 2}$ & $0.87 \pm 0.09$ & $0.95 \pm 0.16$ & $0.35 \pm 0.04$ \\
\hline cisplatin & $12.35 \pm 1.23$ & $43.5 \pm 3.93$ & $16.75 \pm 2.33$ \\
\hline
\end{tabular}




\section{CONCLUSIONS}

In this study, we report on the synthesis, characterisation and biological evaluation of $\mathrm{Cu}(\mathrm{II})$ $2,2^{\prime}: 6^{\prime}, 2^{\prime \prime}$-terpyridine complexes as potential anticancer agents. Terminally functionalised metal complexes of the type $\left[\mathrm{Cu}\left(2,2^{\prime}: 6^{\prime}, 2^{\prime \prime}\right.\right.$-terpyridine $\left.)(\mathrm{Cl})_{2}\right]$ and $\left[\mathrm{Cu}\left(2,2^{\prime}: 6^{\prime}, 2^{\prime \prime}\right.\right.$ terpyridine) $\left.{ }_{2}\right]\left[\mathrm{NO}_{3}\right]_{2}$ were synthesised and characterized by HR-MS and IR spectroscopy. Several compounds were further characterised by single crystal X-ray diffraction studies. Due to poor water solubility of the mono-coordinated complexes, only the bis-coordinated complexes were investigated in a human adenocarcinomic alveolar basal epithelial cell model. The complexes, except for the carboxylic acid functionalised derivative, were found to have a cytotoxicity in the nanomolar range, an order of magnitude more toxic than the clinically applied anticancer agent cisplatin. Promisingly, the compounds had an equal effect in the corresponding cisplatin resistant cancer cell line, making them potentially useful for applications to overcome drug resistant cancers.

\section{ACKNOWLEDGEMENTS}

This work was financially supported by an ERC Consolidator Grant PhotoMedMet to G.G. (GA 681679), has received support under the program Investissements d' Avenir launched by the French Government and implemented by the ANR with the reference ANR-10-IDEX-0001-02 PSL (G.G.), the National Science Foundation of China (Nos. 21525105 and 21778079 for H.C.) and the 973 Program (No. 2015CB856301 for H.C.).

\section{REFERENCES}

[1] F. Bray, A. Jemal, N. Grey, J. Ferlay, D. Forman, Lancet Oncol., 13 (2012) 790-801.

[2] A. Urruticoechea, R. Alemany, J. Balart, A. Villanueva, F. Vinals, G. Capella, Curr.

Pharm. Des., 16 (2010) 3-10.

[3] G. Gasser, Chimia, 69 (2015) 442-446.

[4] J. Karges, ChemBioChem, (2020) accepted, doi: 10.1002/cbic.202000397.

[5] P. Pil, S.J. Lippard, Cisplatin and Related Drugs, in: J.R. Bertino (Ed.) Encyclopedia of Cancer (Second Edition), Academic Press, New York, 2002, pp. 525-543.

[6] T.C. Johnstone, K. Suntharalingam, S.J. Lippard, Chem. Rev., 116 (2016) 3436-3486.

[7] F.-S. Liu, Taiwan. J. Obstet. Gyne., 48 (2009) 239-244.

[8] J. Karges, T. Yempala, M. Tharaud, D. Gibson, G. Gasser, Angew. Chem. Int. Ed., 59 (2020) 7069-7075. 
[9] I. Ott, R. Gust, Arch. Pharm. Chem. Life Sci., 340 (2007) 117-126.

[10] E. Hillard, A. Vessières, L. Thouin, G. Jaouen, C. Amatore, Angew. Chem. Int. Ed., 45 (2006) 285-290.

[11] D. Schlawe, A. Majdalani, J. Velcicky, E. Heßler, T. Wieder, A. Prokop, H.-G. Schmalz, Angew. Chem. Int. Ed., 43 (2004) 1731-1734.

[12] J. Karges, U. Basu, O. Blacque, H. Chao, G. Gasser, Angew. Chem. Int. Ed., 58 (2019) 14334-14340.

[13] I. Ott, K. Schmidt, B. Kircher, P. Schumacher, T. Wiglenda, R. Gust, J. Med. Chem., 48 (2005) 622-629.

[14] D.C. Ware, B.D. Palmer, W.R. Wilson, W.A. Denny, J. Med. Chem., 36 (1993) 18391846.

[15] J. Karges, O. Blacque, H. Chao, G. Gasser, Inorg. Chem., 58 (2019) 12422-12432.

[16] F. Caruso, M. Rossi, Mini-Rev. Med. Chem., 4 (2004) 49-60.

[17] Z. Yu, J.A. Cowan, Curr. Opin. Chem. Biol., 43 (2018) 37-42.

[18] C.M. Agbale, M.H. Cardoso, I.K. Galyuon, O.L. Franco, Metallomics, 8 (2016) 11591169.

[19] J.C. Joyner, J. Reichfield, J.A. Cowan, J. Am. Chem. Soc., 133 (2011) 15613-15626.

[20] D.S. Sigman, D.R. Graham, V. D'Aurora, A.M. Stern, J. Biol. Chem., 254 (1979) 12269 12272.

[21] C. Wende, C. Lüdtke, N. Kulak, Eur. J. Inorg. Chem., 2014 (2014) 2597-2612.

[22] C. Santini, M. Pellei, V. Gandin, M. Porchia, F. Tisato, C. Marzano, Chem. Rev., 114 (2014) 815-862.

[23] T.J.P. McGivern, S. Afsharpour, C.J. Marmion, Inorganica Chim. Acta, 472 (2018) 1239.

[24] M. Cristina, P. Maura, T. Francesco, S. Carlo, Anticancer Agents Med. Chem., 9 (2009) $185-211$.

[25] T. Saverio, M. Luciano, Curr. Med. Chem., 16 (2009) 1325-1348.

[26] L. Ruiz-Azuara, M.E. Bravo-Gomez, Curr. Med. Chem., 17 (2010) 3606-3615.

[27] R. Galindo-Murillo, J.C. García-Ramos, L. Ruiz-Azuara, T.E. Cheatham, III, F. CortésGuzmán, Nucleic Acids Res., 43 (2015) 5364-5376.

[28] J. Serment-Guerrero, P. Cano-Sanchez, E. Reyes-Perez, F. Velazquez-Garcia, M.E. Bravo-Gomez, L. Ruiz-Azuara, Toxicol. In Vitro, 25 (2011) 1376-1384.

[29] J.R. Williams, E. Trias, P.R. Beilby, N.I. Lopez, E.M. Labut, C.S. Bradford, B.R. Roberts, E.J. McAllum, P.J. Crouch, T.W. Rhoads, C. Pereira, M. Son, J.L. Elliott, M.C. Franco, A.G. Estévez, L. Barbeito, J.S. Beckman, Neurobiol. Dis., 89 (2016) 1-9.

[30] A.L. Vāvere, J.S. Lewis, Dalton Trans., (2007) 4893-4902.

[31] K. Suntharalingam, D.J. Hunt, A.A. Duarte, A.J.P. White, D.J. Mann, R. Vilar, Chem.

Eur. J., 18 (2012) 15133-15141.

[32] K. Suntharalingam, A.J.P. White, R. Vilar, Inorg. Chem., 49 (2010) 8371-8380.

[33] J. Grau, A. Caubet, O. Roubeau, D. Montpeyó, J. Lorenzo, P. Gamez, ChemBioChem, 21 (2020) 2348-2355.

[34] A. Kumar, J. Prakash Chinta, A. Kumar Ajay, M. Kumar Bhat, C.P. Rao, Dalton Trans., 40 (2011) 10865-10872.

[35] J.-W. Liang, Y. Wang, K.-J. Du, G.-Y. Li, R.-L. Guan, L.-N. Ji, H. Chao, J. Inorg. Biochem., 141 (2014) 17-27.

[36] J. Grau, R.F. Brissos, J. Salinas-Uber, A.B. Caballero, A. Caubet, O. Roubeau, L. Korrodi-Gregório, R. Pérez-Tomás, P. Gamez, Dalton Trans., 44 (2015) 16061-16072. [37] E.C. Constable, M.D. Ward, J. Chem. Soc., Dalton Trans., (1990) 1405-1409.

[38] S. Katagiri, R. Sakamoto, H. Maeda, Y. Nishimori, T. Kurita, H. Nishihara, Chem. Eur. J., 19 (2013) 5088-5096. 
[39] E.C. Constable, K. Harris, C.E. Housecroft, M. Neuburger, J.A. Zampese, CrystEngComm, 12 (2010) 2949-2961.

[40] M.W. Cooke, P. Tremblay, G.S. Hanan, Inorganica Chim. Acta, 361 (2008) 2259-2269. [41] E.C. Constable, A.M.W.C. Thomson, D.A. Tocher, M.A.M. Daniels, New J. Chem., 16 (1992) 855-867.

[42] R.C. Clark, J.S. Reid, Acta Cryst. A, 51 (1995) 887-897.

[43] Rigaku OD (2019). CrysAlisPro 2011.2171.2040.2053. Rigaku Oxford Diffraction, Yarnton, Oxfordshire, England.

[44] O.V. Dolomanov, L.J. Bourhis, R.J. Gildea, J.A.K. Howard, H. Puschmann, J. Appl. Cryst., 42 (2009) 339-341.

[45] G.M. Sheldrick Acta Cryst. A, (2015) 3-8.

[46] G.M. Sheldrick Acta Cryst. C, (2015) 3-8.

[47] J. Karges, O. Blacque, M. Jakubaszek, B. Goud, P. Goldner, G. Gasser, J. Inorg. Biochem., 198 (2019) 110752.

[48] W. Henke, S. Kremer, D. Reinen, Inorg. Chem., 22 (1983) 2858-2863.

[49] X. Zhou, Z. Huang, Y. Cao, S. Yu, X. Yu, G. Zhao, L. Pu, RSC Adv., 5 (2015) 5390553910.

[50] V.M. Manikandamathavan, V. Rajapandian, A.J. Freddy, T. Weyhermüller, V.

Subramanian, B.U. Nair, Eur. J. Med. Chem., 57 (2012) 449-458.

[51] G. Zhang, E. Liu, C. Yang, L. Li, J.A. Golen, A.L. Rheingold, Eur. J. Inorg. Chem., 2015 (2015) 939-947.

[52] M.I. Arriortua, T. Rojo, J.M. Amigo, G. Germain, J.P. Declercq, Acta Cryst. B, 38 (1982) 1323-1324.

[53] A. Meyer, G. Schnakenburg, R. Glaum, O. Schiemann, Inorg. Chem., 54 (2015) 84568464.

[54] J. García-Lozano, L. Soto, J.-V. Folgado, E. Escrivá, J.P. Legros, Polyhedron, 15 (1996) 4003-4009.

[55] R. Allmann, W. Henke, D. Reinen, Inorganic Chemistry, 17 (1978) 378-382.

[56] W. Huang, W. You, L. Wang, C. Yao, Inorganica Chim. Acta, 362 (2009) 2127-2135.

[57] N. Zhang, J. Yang, R.-X. Hu, M.-B. Zhang, Z. Anorg. Allg. Chem., 639 (2013) 197-202.

[58] W.W. Fu, Q.W. Cheng, H.Y. Wang, F.Z.R. He, Y. Liu, F.X. Zhang, Russ. J. Coord., 43 (2017) 547-558. 